\title{
Mastication Effects on Cattle Diet Deter- mined by Microhistological Analysis
}

\author{
BRYAN D. GROSS, ELFATIH MAHGOUB, AND JERRY L. HOLECHEK
}

\begin{abstract}
This study examined the infuence of mastication on the composition of several hand compounded diets fed to esophageally fistulated cattle. Microhistological analysis was used to determine diet sample botanical composition. Mastication had no effect on diet botanical composition. However, considerable variation existed between observers. The use of observers demonstrating high accuracy with hand compounded mixtures and replication of observers are possible ways to maintain accuracy when microhistological analysis is used to evaluate herbivore diets.
\end{abstract}

Much of the recent research concerning food habits of grazing animals has involved the use microhistological analysis. Accuracy of the technique with hand compounded diets has been well established (Holechek et al. 1982a). However, research is unavailable on the influence of ingestion and mastication on diet botanical composition when microhistological analysis is used. Knowledge of this effect would aid in the interpretation of diet botanical composition data when fistulated animals are used as sampling agents. The objective of this study was to determine the influence of mastication on botanical composition of diet samples collected with esophageally fistulated cattle.

\section{Methods}

During the summer of 1980 , growing plant material was obtained from 12 forage plants common to southcentral New Mexico. These plant materials were dried, chopped into pieces not shorter than $8 \mathrm{~cm}$, and hand compounded into diets (Table 1). Immature plant materials were selected because they are more sensitive to the action of mastication and salivation than are mature plants (Wilkinson et al. 1969).

Approximately one half of each hand compounded diet was fed to an esophageally fistulated cow. The masticated samples were dried, and both the masticated and unmasticated portions of each diet were ground through a micro-Wiley mill with a $1-\mathrm{mm}$ screen. Ten slides were prepared for both the masticated and unmasticated portions of each diet. Slide preparation involved soaking diet materials for one half hour in $0.05 \mathrm{M} \mathrm{NaOH}$. Hertwig's clearing and Hoyer's mounting solutions were used in the preparation of all slides (Sparks and Malechek 1968).

Three observers trained by the procedures of Holechek and Gross (1982a) were used to read each set of 10 slides for the various treat ment/diet combinations. The actual botanical composition of the diets was unknown to the observers. Twenty microscope fields were read on each slide. Slides were prepared so that at least 20 frequency observations were recorded per slide. The level of precision for each observer for each diet species composition was approximately $95 \%$ confidence that the estimate was within $5 \%$ of the mean (Holechek and Vavra 1981). The relative percent by weight composition of each diet was calculated by dividing the

Authors are graduate research assistants and associate professor, Department of Animal and Range Sciences, New Mexico State University, Las Cruces 88003.

This report is Journal Article 847. Agricultural Experiment Station, New Mexico State University, Las Cruces, 88003.

Manuscript received February 27, 1982
Table 1. Means for masticated and unmasticated hand compounded diets on the basis of percent by weight composition.

\begin{tabular}{|c|c|c|c|}
\hline & \multicolumn{2}{|c|}{ Estimated } & \multirow[b]{2}{*}{ Actual } \\
\hline I & $\begin{array}{l}\text { Unmasti- } \\
\text { cated }\end{array}$ & $\begin{array}{l}\text { Masti- } \\
\text { cated }\end{array}$ & \\
\hline \multicolumn{4}{|l|}{ Mixture 1} \\
\hline Black grama (Bouteloua eriopoda) & 34 & 36 & 33 \\
\hline Russian thistle (Salsola kali) & 32 & 31 & 33 \\
\hline Gray oak (Quercus grisea) & 34 & 33 & 33 \\
\hline \multicolumn{3}{|l|}{ Mixture 2} & . \\
\hline $\begin{array}{l}\text { Blue grama (Bouteloua gracilis) } \\
\text { Faintcrown (Aphanostephus }\end{array}$ & 34 & 35 & 33 \\
\hline ramosissimum) & 31 & 31 & 33 \\
\hline Desert willow (Chilopsis linearis) & 35 & 34 & 33 \\
\hline \multicolumn{4}{|l|}{ Mixture 3} \\
\hline $\begin{array}{l}\text { Silver bluestem (Bothriochloa } \\
\text { saccharoides) }\end{array}$ & 36 & 35 & 33 \\
\hline $\begin{array}{l}\text { Leatherleaf croton (Croton } \\
\text { corymbulosus) }\end{array}$ & 34 & 32 & 33 \\
\hline Fourwing saltbush (Atriplex canescens) & 30 & 33 & 33 \\
\hline \multicolumn{4}{|l|}{ Mixture 4} \\
\hline Red threeawn (Aristida longiseta) & 36 & 36 & 33 \\
\hline Globemallow (Sphaeralcea incana) & 31 & 31 & 33 \\
\hline $\begin{array}{l}\text { Mountain mahogany (Cercocarpus } \\
\text { breviflorus) }\end{array}$ & 33 & 33 & 33 \\
\hline
\end{tabular}

number of frequency observations for each species by the total number of frequency observations for all species (Holechek and Gross 1982b).

Multivariate analysis of variance (MANOVA) was used to determine if the difference existed between masticated and unmasticated diet samples. The 3 observers were used as replications and the 12 species in the 4 diets were used as variates. This resulted in an experimental design with 6 total vectors comprised of 12 variates. A detailed discussion of the use of MANOVA for analysis of biological data is provided by Pimentel (1979). The individual variance and mean associated with each species was used in the standard $t$-test to determine if actual and estimated values differed significantly (Steel and Torrie 1960). This variance was partitioned into treatment and error components; the $F$-test was then applied to evaluate mastication effects (Steel and Torrie 1960). Similarity between observed and estimated diets for each observer was evaluated using Kulcyznski's formula discussed by Oosting (1956).

\section{Results}

MANOVA indicated mastication had no overall effect $(P<.05)$ on diet composition; none of the individual species was affected $(R<.05)$ by mastication (Table 1). Estimated and actual values were not significantly different $(P<.05)$ for any of the individual species.

Considerable variation occurred between observers in this study. Observers 2 and 3 were consistent and accurate in their 
Table 2. Percent similarity between estimated and actual diet botanical composition of the 3 observers for masticated and unmasticated hand compounded diets.

\begin{tabular}{lccccccc}
\hline & \multicolumn{3}{c}{ Unmasticated } & & \multicolumn{3}{c}{ Masticated } \\
\cline { 2 - 4 } \cline { 7 - 8 } \cline { 7 - 8 } & Obs. 1 & Obs. 2 & Obs. 3 & & Obs. I & Obs. 2 & Obs. 3 \\
\hline Mixture 1 & 84 & 97 & 97 & & 85 & 98 & 94 \\
Mixture 2 & 78 & 97 & 96 & & 79 & 96 & 97 \\
Mixture 3 & 91 & 96 & 96 & & 93 & 96 & 96 \\
Mixture 4 & 96 & 96 & 96 & & 98 & 96 & 96 \\
\hline
\end{tabular}

estimates of botanical composition of each mixture. However, estimates of observer 1 were different from those of observers 2 and 3 , and much lower in accuracy (Table 2). The average coefficient of variation between observers 2 and 3 was $5 \%$. However, when observer 1 was included, the average coefficient of variation increased to $21 \%$. Holechek et al. (1982b) found that observer had far greater influence on the results of microhistological analysis than either sample preparation or plant growth stage. They recommended that observer accuracy should be evaluated with hand compounded mixtures and that observers should be replicated if accuracy is critical.

Apparently mastication has little or no influence on results when microhistological analysis is used to evaluate botanical composition of samples obtained from esophageally fistulated animals. This and other studies reviewed by Holechek et al. (1982a) have demonstrated esophageal fistula sampling coupled with microhistological analysis can provide accurate data on the botanical composition of the grazing animal's diet.

The largest source of error associated with microhistological analysis results from the observers. This source of crror should be evaluated by replication and the use of hand compounded mixtures if accuracy is important. Replication of observers is less essential it diet trends with time or relative diet diffe rences between different species of animals are of primary concern. This is particularly true if the observer demonstrates high accuracy with hand compounded mixtures.

\section{Literature Cited}

Holechek, Jerry L., and Bryan D. Gross. 1982a. Training needed for quantifying simulated diets from fragmented range plants. J. Range Manage. 35:644-647.

Holechek, Jerry L., and Bryan D. Gross. 1982b. Evaluation of diet calculation procedures for microhistological analysis. J. J. Range Manage. 35:743-745.

Holechek, Jerry L., and Martin Vavra. 1981. The effect of slide and frequency observation numbers on the precision of microhistological analysis. J. Range Manage. 34:337-338.

Holechek, Jerry L., Rex D. Pieper, and Martin Varra. 1982a. Methods for determining the botanical composition of range herbivore diets. J. Range Manage. 35:309-316.

Holechek, Jerry L., Bryan D. Gross, Sira Mady Dabo, and Thor Stephenson. $1982 \mathrm{~h}$. Effects of sample preparation, growth stage and observer on microhistological analysis of herbivore diets. J. Wildl. Manage. 46:502505.

Oosting, H.J. 1956. The study of plant communities. W.H. Freeman and Company, San Francisco.

Sparks, D.R., and J.C. Malechek. 1960. Estimating percentage dry weight in diets using a microscope technique. J. Range Manage. 21:264-265.

Steel, R.G., and J.H. Torrie. 1960. Principles and procedures of statistics. McGraw-Hill Book Co., New York.

Wilkinson, S.R., R.N. Dawson, and W.E. Adams. 1969. Effects of sample drying procedure on chemical composition and in vitro digestibility of coastal bermuda. Agron. J. 61:457-460.

\title{
RANGELAND HYDROLOGY
}

\author{
by Farrel A. Branson, Gerald F. Giftord, Kenneth G. Renard, and \\ Richard F. Hadley
}

Unique in its emphasis on the hydrology of rangelands, primarily arid and semiarid lands, RANGELAND HYDROLOGY provides a text for one aspect of range management where none has existed before. This expanded Second Edition presents in-depth information for those who must manage rangeland or respond to questions about the impacts of land use practices on hydrology.

Included in the new Second Edition are a chapter on modeling with approaches to predicting the effects of land use, and a chapter on the rapidly developing field of snow pack management.

The 352-pages include 197 illustrations, providing rapid access to an assembly of data found nowhere else and useful in the preparation of environmental impact statements. Extensive bibliographic material with each chapter and a subject matter index add to the useableness of the book.

Range scientists and managers, soil conservationists, hydrologists, agricultural engineers, land reclamation specialists, wildlife managers, graduate and undergraduate students and their professors, as well as all interested in the hydrology of arid lands will find RANGELAND HYDROLOGY a valuable addition to their libraries. (352 pages paper laminated cover $\$ 15.00$ US) 